\title{
The Role of Emergent Aquatic Macrophytes in Changing Water Quality at Al-Shafi Marsh, Southern Iraq
}

\author{
دور النباتات المائية البارزة في تغيير نوعية المياه في هور الثافي جنوب العراق
}

\author{
Mohammed A. Al-Kenzawi , Altaf A. Al-Rawi \\ Biology Dept./ College of Science for Women/ University of Baghdad
}

$$
\begin{aligned}
& \text { محمد عبد الرضا الكنزاوي ألطاف عبد الواحد الراوي } \\
& \text { قسم علوم الحياة/ كلية العلوم للبنات/ جامعة بغداد الكياد }
\end{aligned}
$$

\section{Abstract:}

This study was done at Al-Shafi marsh, southern Iraq, to determine the role of emergent aquatic macrophytes in changing the water quality. Three dominant emergent aquatic macrophytes were identified in the marsh and the vegetation cover percentages for them were measured, which were Phragmites australis covers 40\%, Typha domengensis covers $30 \%$, and Schoinoplectus litoralis covers $15 \%$, while the other $15 \%$ was open water. The water environmental variables [pre the marsh, in the marsh (distributed emergent macrophytes), and post the marsh] were measured. The statistical program t-test was applied at the significant levels $(P$-value $<0.01)$ and $(P$-value $<0.05)$ to know the significant differences in the environmental variables among the sites. This study showed that light penetration, total suspended solids, water turbidity, nitrate, nitrite, and phosphate concentrations differed significantly $(P<0.01)$. While, Water temperature, $\mathrm{pH}$, dissolved oxygen, calcium, and magnesium were differed significantly $(P<0.05)$ among the sites. In addition, no significant differences in electrical conductivity, salinity, and chloride were observed by emergent macrophytes. Therefore, this study concluded that emergent macrophytes play important role in changing some water characteristics.

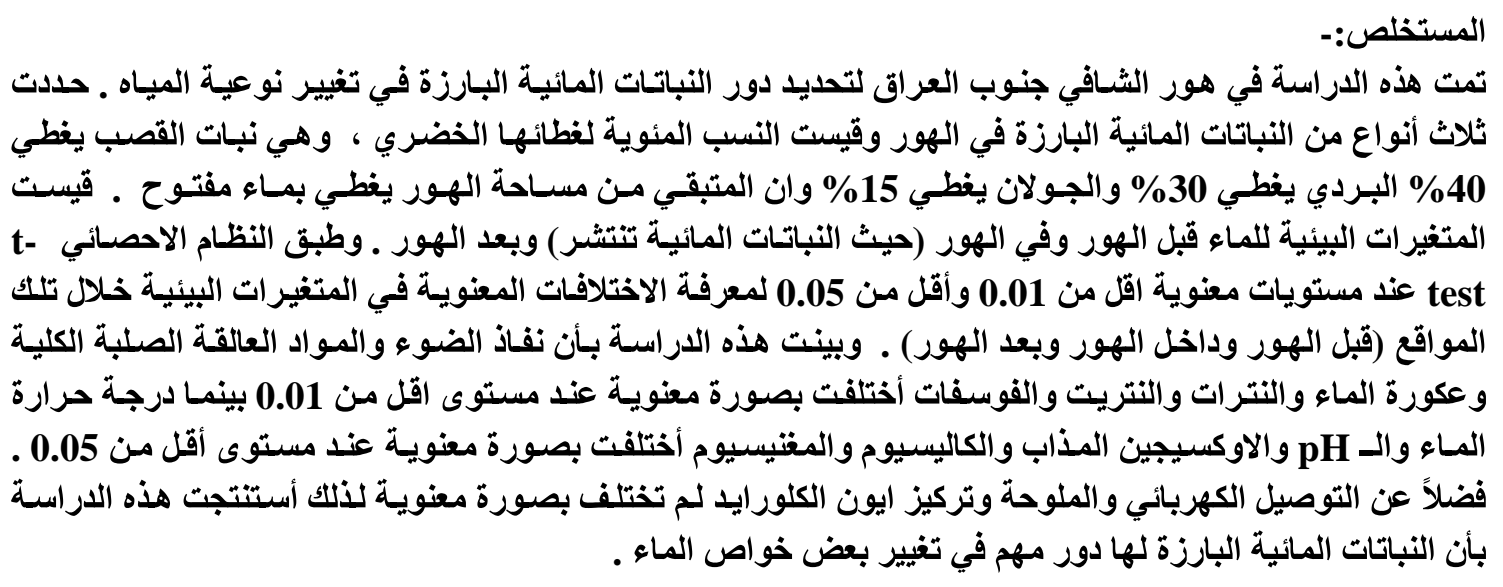

Keywords: Iraqi Marshes. Emergent Aquatic Macrophytes. Water Quality Changing. 


\section{Introduction:}

The Tigris and Euphrates rivers have created about $15,000 \mathrm{~km}^{2}$ of wetlands known as the Mesopotamian marshes. These wetlands comprise a complex of interconnected shallow freshwater lakes and marshlands, which are considered the most extensive wetland ecosystem in the Middle East [1]. Water levels reach their maximum in early spring and then fall by as much as two meters during the hot dry summer [2].

Iraqi marshes ultimately drain southeast wards into the Gulf via the Shatt Al-Arab waterway [3]. Floodplain wetlands, riverbanks and lake shores are utilized for the cultivation of cereals, rice or vegetables, while the rivers and lakes themselves support freshwater fisheries. One of the most serious threats to the wetlands in Iraq has been the drainage and diversion of water, as typically supply for agricultural purposes, but also in recent years, for military reasons [3]. Within the last few years, major hydrological engineering activities in and around the area of Lower Mesopotamia have resulted in the drying out of vast areas of wetlands in the Central Marches and Al-Hammar, and could eventually lead to the disappearance of these systems [4]. Currently, less than $10 \%$ of the marshlands in Iraq remain as fully functioning wetlands because of the extensive drainage and upstream agricultural irrigation programs on Tigris and Euphrates rivers [3]. The Marsh Arabs, or Ma'dan, who have lived in the marshes for at least 5,000 years, have been particularly affected by these actions [1]. Currently, restoration by reflooding of drained marshes is proceeding in the Central and Al-Hammar marshlands [5].

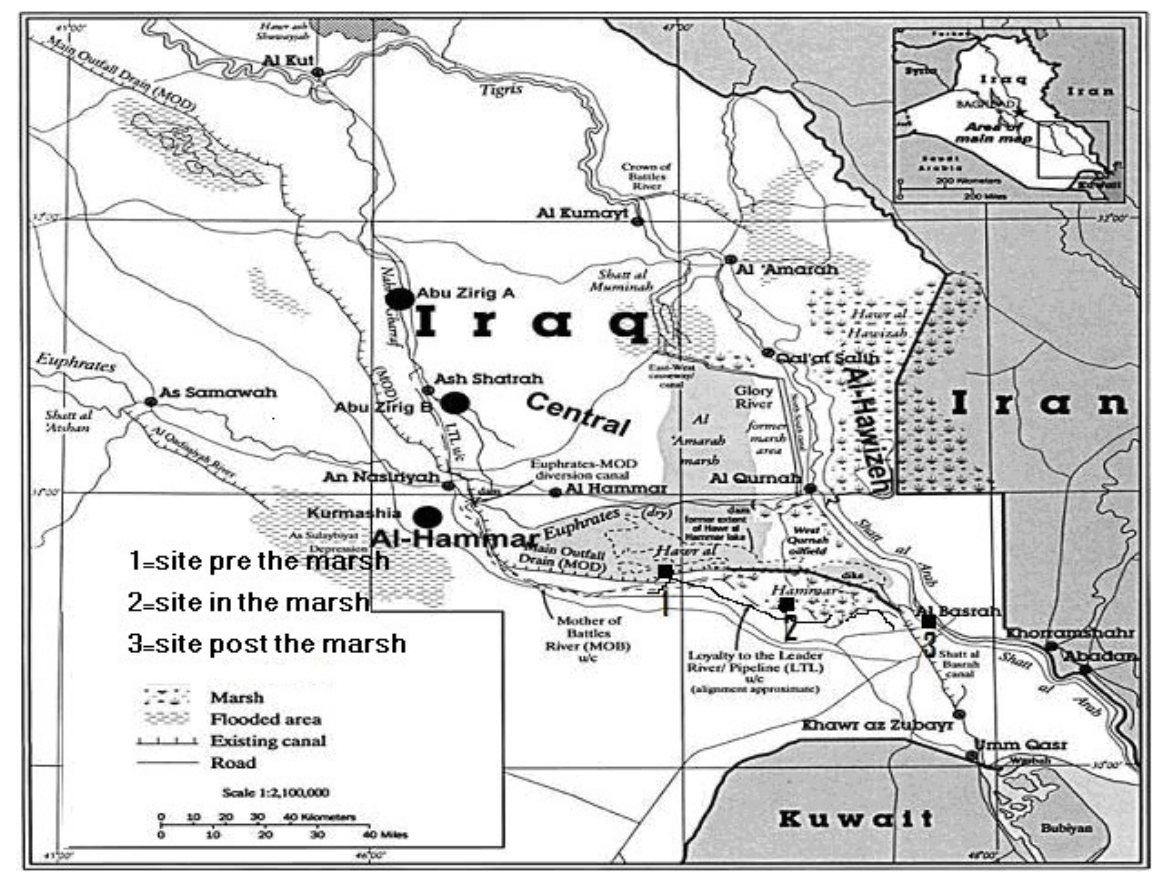

Fig (1): Southern Iraqi Marshes 
Water quality improving in wetlands include surface flow marshes, vegetated subsurface flow beds (found mostly in Europe, and vegetated with Phragmites australis), submerged aquatic beds, and beds of floating plants such as Eichhornia crassipes, as well as other types [6]. Water quality treatment by aquatic plants become widespread because, in general, they have effect on the suspended solids, turbidity, calcium, magnesium, oxygen demand, nitrogen, phosphorus, and some metals [7]. The removal of excess nutrient loadings is essential to the health of aquatic ecosystem. In treatment wetlands, nutrient and solids removal is facilitated by shallow water, high primary productivity, the presence of aerobic and anaerobic sediments, and the accumulation of dead plant parts [8].

Some metals are essential micronutrients plants, but in wastewaters they may be in concentrations that are toxic to sensitive organisms. Biomagnification through the food chain occurs with a number of metals. For this reason, it is essential that removed from wastewater flows before they enter natural water [9].

The aquatic macrophytes have physical effects on the water quality, these effects including negative effect on the water velocity and allow for the filtering and settling of organic particulate matter and other suspended solids [10,11]. Aquatic macrophytes play important role in uptake the nutrients from water [12].

The aquatic macrophyte species of all growth forms have been used in treatment of aquatic system, this treatment should not be invasive species; they should be tolerant of the local environmental conditions and of pollutants, and they should be easily established [13].

The main objectives of this study are to determine the characteristics of water, and the role of aquatic macrophyte in improving water quality in Al-Shafi Marshes-Southern Iraq.

\section{Materials and Methods:}

\section{Floristic Study}

The studied macrophytes species were identification in the herbarium of College of Science in the University of Basrah according to [14].

Vegetation Cover percentage is defined as the area of ground within the quadrate, which is occupied aboveground parts of each species when viewed from above. Cover was estimated usually as a percentage. Whereas area of the quadrate is one $\mathrm{m}^{2}$ [15].

\section{Environmental variables}

The environmental variables were measured according to [16]. Five water samples were taken in each site (before the marsh, in the marsh, and after the marsh) during June-2007. When the water temperature, electrical conductivity, salinity, and water $\mathrm{pH}$ were measured directly in the field by digital portable multi meter (model 340i/SET). While, water turbidity was measured by portable digital turbidity meter, type Hana. Light penetration was measured by Secchi disk (30 $\mathrm{cm}$ in diameter). TSS was measured by filtration throughout the dried and weighed filter papers (GF/C 0.45 micrometers). Dissolved oxygen was measured by Azidemodification of Winkler method. Calcium ion concentration was measured by titration against standard EDTA $(0.01 \mathrm{M})$. While, the nutrients $\left(\mathrm{NO}_{3}, \mathrm{NO}_{2}\right.$, and $\left.\mathrm{PO}_{4}\right)$ were measured by coloremetric methods. 


\section{Statistical analysis}

The statistical significance of difference for data among locations was assessed using t-test. $P$-value less than the point 0.01 and 0.05 level of significance were considered statistically significant [17].

\section{Results :}

First, three dominant emergent macrophyte communities were determined in Al-Shafi Marsh, which are Phragmites australis, Typha domengensis and Schoinoplectus litoralis. Their vegetation cover percentages are $40 \%, 30 \%$, and 15\% respectively. In addition, some variations were observed in the some of environmental variables, which are including water temperature changed from $26.7 \mathrm{C}^{\circ}$ pre the marsh to $19.2 \mathrm{C}^{\circ}$ in the marsh and $23.5 \mathrm{C}^{\circ}$ post the marsh. Total suspended solids changed from $20.13 \mathrm{mg} / \mathrm{l}$ pre the marsh to $3.77 \mathrm{mg} / \mathrm{l}$ post the marsh. Water turbidity changed from 13.01 NTU to 1.25 NTU. Light penetration changed from $75 \%$ to $100 \%$. Water $\mathrm{pH}$ increased from 7.2 to 7.4 . Dissolved oxygen was declined during the study time, when its value ranged from $3.8 \mathrm{mg} / \mathrm{l}$ before the marsh to 4.6 in the marsh (where the macrophytes distribute). Calcium ion decreased from $268.4 \mathrm{mg} / \mathrm{l}$ before the marsh to $180.6 \mathrm{mg} / \mathrm{l}$ after the marsh. Magnesium ion decreased from $94.2 \mathrm{mg} / \mathrm{l}$ to $42.2 \mathrm{mg} / \mathrm{l}$ after the marsh. Nitrate concentration decreased from $2.7 \mu \mathrm{g} / 1$ to pre the marsh to $1.1 \mu \mathrm{g} / \mathrm{l}$ post the marsh. Nitrite concentration decreased from $0.91 \mu \mathrm{g} / 1$ pre the marsh to $0.44 \mu \mathrm{g} / 1$ post the marsh. Phosphate concentration decreased from $1.09 \mu \mathrm{g} / 1$ pre the marsh to $0.51 \mu \mathrm{g} / 1$ post the marsh. While, Chloride ion concentration, electrical conductivity, and salinity were not changed, clearly. These are clear in table (1). By t-test statistical analysis, the results of this study showed the significant effects for emergent macrophytes on the some environmental characteristics. Water temperature, $\mathrm{pH}$, dissolved oxygen, calcium, and magnesium differed significantly $(P<0.05)$. Light penetration, total suspended solids, water turbidity, nitrate, nitrite, and phosphate concentrations differed significantly $(P<0.01)$. While, no significant differences in electrical conductivity, salinity, and chloride were observed. 
Table (1): Vegetation covers percentage and some environmental variables

\begin{tabular}{|c|c|c|c|c|c|c|c|c|c|c|c|c|c|c|c|c|}
\hline Site & $\begin{array}{l}\text { Type of } \\
\text { Macrophytes }\end{array}$ & $\begin{array}{l}\text { Vegetatio } \\
\mathrm{n} \quad \text { cover } \\
(\%)\end{array}$ & $\begin{array}{l}\text { WT } \\
\left(\mathrm{C}^{\circ}\right)\end{array}$ & $\begin{array}{l}\text { TSS } \\
(\mathrm{mg} / \mathrm{l})\end{array}$ & $\begin{array}{l}\text { TUR } \\
\text { (NTU) }\end{array}$ & $\begin{array}{l}\mathrm{LP} \\
(\%)\end{array}$ & $\begin{array}{l}\mathrm{EC} \\
(\mathrm{mS} / \mathrm{cm})\end{array}$ & $\begin{array}{l}\text { Sal. } \\
\text { ppt. }\end{array}$ & $\mathrm{pH}$ & $\begin{array}{l}\mathrm{DO} \\
(\mathrm{mg} / \mathrm{l})\end{array}$ & $\begin{array}{l}\mathrm{Ca}^{+2} \\
(\mathrm{mg} / \mathrm{l})\end{array}$ & $\begin{array}{l}\mathrm{Mg}^{+2} \\
(\mathrm{mg} / \mathrm{l})\end{array}$ & $\begin{array}{l}\mathrm{Cl}^{-1} \\
(\mathrm{mg} / \mathrm{l})\end{array}$ & $\begin{array}{l}\mathrm{NO}_{3} \\
(\mu \mathrm{g} / \mathrm{l})\end{array}$ & $\begin{array}{l}\mathrm{NO}_{2} \\
(\mu \mathrm{g} / \mathrm{l})\end{array}$ & $\begin{array}{l}\mathrm{PO}_{4} \\
(\mu \mathrm{g} / \mathrm{l})\end{array}$ \\
\hline $\begin{array}{l}\text { Pre Al- } \\
\text { Shafi } \\
\text { Marsh }\end{array}$ & & & 26.7 & 20.13 & 13.01 & 75 & 8.79 & 4.7 & 7.2 & 3.8 & 268.4 & 94.2 & 216.8 & 2.7 & 0.91 & 1.09 \\
\hline \multirow{3}{*}{$\begin{array}{l}\text { In Al- } \\
\text { Shafi } \\
\text { Marsh }\end{array}$} & $\begin{array}{l}\text { Phragmites } \\
\text { australis }\end{array}$ & $40 \%$ & \multirow{3}{*}{19.2} & \multirow{3}{*}{17.05} & \multirow{3}{*}{9.13} & \multirow{3}{*}{90} & \multirow{3}{*}{8.51} & \multirow{3}{*}{4.5} & \multirow{3}{*}{7.4} & \multirow{3}{*}{4.6} & \multirow{3}{*}{192.2} & \multirow{3}{*}{60.8} & \multirow{3}{*}{190.2} & \multirow{3}{*}{1.9} & \multirow{3}{*}{0.63} & \multirow{3}{*}{0.75} \\
\hline & $\begin{array}{l}\text { Typha } \\
\text { domengensis }\end{array}$ & $30 \%$ & & & & & & & & & & & & & & \\
\hline & $\begin{array}{l}\text { Schoinoplectus } \\
\text { litoralis }\end{array}$ & $15 \%$ & & & & & & & & & & & & & & \\
\hline $\begin{array}{l}\text { Post Al- } \\
\text { Shafi } \\
\text { Marsh }\end{array}$ & & & 23.5 & 3.77 & 1.25 & 100 & 8.33 & 4.5 & 7.4 & 4.2 & 180.6 & 42.2 & 176.4 & 1.1 & 0.44 & 0.51 \\
\hline
\end{tabular}




\section{Discussion:}

The significant difference in water temperature may be due to the emergent aquatic macrophytes and can have a strong influence on the temperature within the aquatic environment, also plants presence decreases evaporation from the water's surface, whereas more evaporation occurs in open water, also air temperature and radiant energy from the sun have the greatest influence on water temperature [18]. As well as, the vegetation cover declines heat of sun to reach to the water surface [19] that agrees with the present study.

Light penetration is an important parameter because light affects both the biological and chemical reactions in a water-body. If a water-body is very turbid, light will not reach through the water column and many processes, especially photosynthesis, will be limited. When water is turbid, the floating particles absorb heat from the sun, raising water temperature and thus lowering dissolved oxygen levels [20]. Light Penetration in water column is affected by many factors, external factors that include climatic conditions and human activity (boat movement and grazing), and internal factors, including quantity and quality of suspended and dissolved materials, water flow and tidal situation. The aquatic macrophytes play important role in increasing the light penetration, whereas the aquatic plants act as traps and sinking the suspended materials, and the growth of aquatic plants reduce the water flow, which causes reducing of the total suspended solids value. The results of the present study showed the significant effect for emergent macrophytes on light penetration, turbidity, and total suspended solids. These agree with the previous studies about Mesopotamian marsh [20, 21].

Water electrical conductivity is one of the important chemical properties for water, which affect the growth of plants, whereas it is considered one of the limited factors to plant growth [13]. In this study, no significant effect for aquatic macrophytes on the electrical conductivity and salinity, this result agrees with [19].

Water $\mathrm{pH}$ is a measure of the concentration of $\mathrm{H}^{+}$ions in a solution. It has being known that Iraqi waters mainly tend to be alkaline, this agrees with results of [22].

In the present study, the significant effect for aquatic macrophyte on $\mathrm{pH}$ that may be due to degradation of the dead parts of aquatic plants, phytoplankton and organic materials, should be led to increase the production of dissolved carbon dioxide [21, 23].

There are many factors play an important role with increasing and decreasing of dissolved oxygen concentration in water. The significant difference in dissolved oxygen concentration in this study may be due to temperature; the raise of temperature leads the dissolved oxygen concentration to be declined [19]. As well as, the water flow and water depth, whereas the water was semi-stagnant and shallow during summer, this agrees with $[20,21]$. In addition, the peak of growth of aquatic macrophytes was at summer, so that the exchanging gas between atmosphere and water surface should be decreased [19]. As well as, the fluctuations in the dissolved oxygen levels could be related to respiration and photosynthesis macrophytes and aquatic organisms [24].

Calcium ion is considered the main component for cell wall in aquatic plants. Generally, calcium ion was more than magnesium ion concentration, this agrees with [25].

The significant effect for aquatic macrophytes on the calcium ion that may be correlated with its importance for macrophytes growth, also calcium ion is consumed by aquatic 
microbial organisms, which leave with aquatic plants in the same ecosystem [26]. As well as, these bacteriological effects may be possible that divalent cation, $\mathrm{Ca}^{2+}$ can act as enzyme activators or maintain the cellular structure of the bacteria which degrade the dead materials (plant and animals) and that lead to increase the nutrients which are required for macrophytes growth [8].

Magnesium ion is an essential nutrient for plants; it shares in the chlorophyll structure and is used in metabolism of plants [27]; in the same time is important for bacteria, which performs the degradation process for dead materials [28]. The significant effect for emergent macrophytes on the magnesium concentration in the present study may be because the aquatic plants uptake it to share in chloroplast structure and the metabolic processes this result agrees [19].

Availability of nutrients is considered one of the main factors affecting the abundance and composition of aquatic plant assemblages [29]. Of the many nutrients required for growth, nitrogen $(\mathrm{N})$ and phosphorus $(\mathrm{P})$ are the elements typically of shortest supply in aquatic ecosystems and therefore most likely to affect the growth of aquatic macrophytes species [30].

The significant effect for emergent macrophytes on the concentrations of nitrate and nitrite that may be because their importance for plant growth, whereas the nitrogen shares in protein structure, and that metabolic processes, based on protein, leading to increasing in vegetative and reproductive growth and yield is totally dependent upon the adequate supply of nitrogen, that increasing the supply of nitrogen fertilizer increases growth and photosynthesis [19]. As well as, there is strong correlation between photosynthesis and leaf nitrogen content for macrophytes, whereas $75 \%$ from amount of chloroplasts is nitrogen [31]. This agrees with [23, 32].

Phosphorus is one of the limiting nutrients for plants growth in wetlands [8]; and it is considered one of main important nutritious components to growth of aquatic plants, whereas organisms take it and then released by degradation the materials, which are present in sediment [19,33]. The significant effect for emergent macrophytes on the phosphate concentration in this study, that, may be, because the amounts of reactive phosphate which are taken by aquatic plants and phytoplankton [23, 33]. In addition, it is important for plant growth because the phosphate shares in structure of the cell wall, protein, nucleotide and ATP [34]. The result of this study agrees with many studies [19, 30, 33].

\section{Conclusion:}

This study concluded that emergent aquatic macrophytes play important role in changing some water characteristics, such as light penetration, total suspended solids, water turbidity, nitrate, nitrite, phosphate concentrations water temperature, $\mathrm{pH}$, dissolved oxygen, calcium, and magnesium. On the other hand, some water characteristics are not affected emergent aquatic macrophytes, which are electrical conductivity, salinity, and chloride. 


\section{References}

1. Brasington, J. (2002). The Iraqi marshlands:a human and environmental study. In: Nicholson, E., Clark. P., Politics Publishing, London.

2. Al - Saadi, H.A.; Antoine, S.E. and Nurul - Islam, A.K. (1981). Limnological investigation in Al - Hammar marsh area in southern Iraq. Journal of Nova Hedweigia, 35: 157 - 166.

3. Partow, H. (2001). Demise of an ecosystem: the disappearance of the Mesopotamian Marshlands United Nations Environment Program (UNEP). Publication UNEP/DEWA/TR. 01-3, Nairobi, Kenya.

4. Richardson, C.J.; Reiss, P.; Hussain, N.A.; Alwash, A.J. and Pool, D.J. (2005). The restoration of potential of the Mesopotamian marshes of Iraq. Journal of Science, 307:1307-1311.

5. Lawler, A. (2005). Reviving Iraq's wetlands. Journal of Science, 307:1186-1189.

6. Kadlec, R.H. and Knight, R.L. (1996). Treatment Wetland, 893 pp. New York. Lewis Publishers.

7. Brix, H. (1986). Treatment of wastewater in the rhizosphere of wetland plant-the rootzone method. Journal of Water Science and Technology, 19: 107-118.

8. Mitsch, W.J. and Gosselink, J.G. (2000). Wetlands, 3rd edition, 920 pp. New Yourk. John Wiley and Sons.

9. Knight, R.L. (1997). Wildlife habitat and public use benefits of treatment wetlands. Journal of Water Science and Technology, 35: 35-43.

10. Stevenson, J.C.; Ward, L.G. and Kearney, M. S. (1988). Sediment transport and trapping in marsh systems: implications of tidal flux studies. Journal of Marine Geology, 80: 37-59.

11. Brix, H. (1997). Do macrophyte play a role in constructed treatment wetland? Journal of Water Science and Technology, 35: 11-17.

12. Peterson, S. B. and Teal, J. M. (1996). The role of plants in ecologically engineered wastewater treatment systems. Journal of Ecological Engineering, 6: 137-148.

13. Cronk, J.K. and Fennessy, M.S. (2001). Wetland Plants Biology and Ecology. CRC Press LLC. 462 pp.

14. Prescott, G.W. (2001). How to Know the Aquatic Plants; The Pictured Key Nature Series, 3rded. WM.C. Brown Co., Dubuque, Iowa, 177 pp.

15. Kent, M. and Coker, P. (1992). Vegetation description and analysis: a practical approach. Printed and bound in Great Britain by Short Run Press, Exeter. Pp363.

16. APHA, AWWA, WPCF (2003). Standard methods for the examination of water and wastewater. 14th ed. American public Health Association, Washington, DC.

17. Sorlie, D.E. (1995). Medical Biostatistician and Epidemiology: examination and board review. 1sted. Appleton and Lang, Norwalk, Connecticut. Pp: 47-88.

18. Picard, C.R.; Fraser, L.H. and Steer, D. (2005). The Interacting Effects of Temperature and Plant Community Type on Nutrient Removal in Wetland Microcosms. Journal of Bioressource Technology, 96: 1039 - 1047. 
19. Al-Kenzawi, M. A. H. (2007). Ecological study of aquatic macrophytes in the central part of the marshes of Southern Iraq. Baghdad University-College of Science for Women. 270 pp.

20. Hussein, N.A. and Taher, M.A. (2007). Effect of daily variations, diurnal fluctuations and tidal stage on water parameters of East Hammar marshland, Southern Iraq. Journal of Marsh Bulletin, 2(1): 32 - 42.

21. Al - Obaidi, G.S.A. (2006). A Study of phytoplankton community in Abu Zirig marsh, Southern Iraq. M.Sc. Thesis, University of Baghdad, Iraq, 102 pp.

22. Hassan, F.M.; Kathim, N.F. and Hussein, F.H. (2007). The effect of chemical and physical properties of River water in Shatt $\mathrm{Al}$ - Hilla on phytoplankton communities. Journal of Chemistry, 5: 24-33.

23. Kassim, T.I. (1986). An Ecological Study on Benthic Algae for some marshlands Southern Iraq. M.Sc. Thesis, University of Basrah.

24. Mermillod - Blondin, F.; Gaudet, J.; Gérino, M.; Desrosiers, G. and des Châtelliers, M.C. (2003). Influence of Macroinvertebrates on Physico - Chemical and Microbial Processes in Hyporheic Sediments. Journal of Hydro. Process. 17: 779-794.

25. Adam, R.S.; Al - Shawi, I.J.M. and Al - Imarah, F.J.M. (2007). Distribution of some chemical elements in the marsh lands of Southern Iraq after rehabilitation. Journal of Marsh Bulletin, 2(1): 11 - 17.

26. Roache, M.C.; Bailey, P.C. and Boon, P.I. (2006). Effects of Salinity on The Decay of the Freshwater Macrophyte, Triglochin procerum. Journal of Aquatic Botany, 84: $45-52$.

27. Antoine, S.E. and Al - Saadi, H.A. (1982). Limnological studies on the polluted Ashar Canal and Shatt Al - Arab River at Basrah, Iraq. Journal of Int. Revue ges. Hydrobiol., 67(3): $405-418$.

28. Boon, P.I. (2000). Carbon cycling in Australian wetlands: The importance of methan. Journal of Verh. Int. Ver. Theor. Angew. Limnol., 27: 1 - 14.

29. Van, T.K.; Wheeler, G.S. and Center, T.D. (1999). Competition between Hydrilla verticillata and Vallisneria americana as influenced by soil fertility. Journal of Aquatic Botany, 62: 225 - 233.

30. Carr, G.M. and Chambers, P.A. (1998). Macrophyte growth and sediment phosphorus and nitrogen in Canadian Prairie River. Journal of Freshwater Biology, 39: 525 - 536.

31. Cechin, I. and Fumis, T.D. (2004). Effect of nitrogen supply on growth and photosynthesis of sunflower plants grown in the greenhouse. Journal of Plant Science, 166: 1379 - 1385.

32. Thomaz, S.M.; Chambers, P.A.; Pierini, S.A. and Pereira, G. (2007). Effects of Phosphorous and Nitrogen Amendment on the Growth of Egeria najas. Journal of Aquatic Botany, 86: 191 - 196.

33. Al-Kenzawi, M. A. H. (2009). Seasonal changes of nutrient concentration in water of some locations in southern Iraqi Marshes, after restoration. Journal of Um-Selmma. In Press. 
34. Ashihara, H.; Li, X.N. and Ukaji, T. (1988). Effect of inorganic phosphate on the biosynthesis of purine and pyrimidine nucleotides in the suspensioncultured cells of Catharanthus roseus. Journal of Anal. Botany, 61:225 $\square 232$. 